Self-assessed health, reference levels, and mortality

Hendrik Jürges

57-2004 


\title{
Self-assessed health, reference levels, and mortality
}

\author{
Hendrik Jürges \\ University of Mannheim and DIW Berlin
}

Revised version: January 2005
Mannheim Research Institute for the Economics of Aging
University of Mannheim
L13, 17
D-68131 Mannheim
Germany
Tel: +49-621-181-3519
Fax: +49-621-181-1863
Email: juerges@mea.uni-mannheim.de.

\begin{abstract}
The paper studies the relationship between self-assessed health and subsequent mortality in the German Socio-Economic Panel. Specifically, I examine whether socioeconomic characteristics of respondents have an effect on mortality, conditional on selfassessed health. Such conditional effects are shown to exist for various covariates, including age, income, and wealth. These findings question the comparability of self-assessed health across different socio-economic groups.
\end{abstract}

Keywords: Self-assessed health; Response bias; Mortality.

JEL-Codes: C42, I12 


\section{Introduction}

The purpose of this paper is to study the nature of the relationship between self-assessed health (SAH) and mortality in the German Socio-economic Panel (SOEP). Self-assessed health is the most common measure of health in general purpose surveys and often the only available indicator of the respondents' health. Respondents are asked to give an overall judgement of their health: "How is your health in general?". Answers are recorded on a 5point Likert-scale ranging from "excellent" to "poor" or "very good" to "very poor". The SOEP contains the second variant. The relationship between self-assessed (and also, for that matter, diagnosed) health and future mortality is of course not perfect. Since self-assessed health is a measure of an individual's overall health status, not every chronic condition that affects self-assessed health is life-threatening or life-shortening. For instance, a well-known finding in epidemiology is that women are more likely to suffer from chronic diseases but are less likely to die at each age (see Case \& Paxson, 2004, on sex differences in health). Further, not every future mortality risk is known to the respondent, and even if it was known, it would not necessarily affect self-assessed health. Despite these conceptual shortcomings, previous research has shown that there is a strong independent relationship between self-assessed health and subsequent mortality (see Idler \& Benyiamini, 1997; Benyiamini \& Idler, 1999).

This paper is one of the first to use the SOEP for the analysis of self-reported health and subsequent mortality. To the best of my knowledge, there is only one other study based on the SOEP that deals with this issue (Schwarze, Andersen \& Anger, 2000). However, Schwarze et al. do not address the comparability of self-rated health across different socio-economic groups. But comparisons of self-reports of health across different populations (e.g., across countries, languages, sexes, education and income levels, etc.) are only possible if these measures are in fact comparable. Mortality is a fairly objective indicator of health, and the relationship between self-reported health status and subsequent mortality contains information about differences in self-reports that are not necessarily differences in true health states. One major concern with self-assessed health is that respondents may have different response styles or different reference points against which they judge their health. This gives rise to a fundamental identification problem, namely to distinguish differences in true health from differences in reporting behaviour. 
For instance, a common finding is that older respondents tend to have a "milder" view of their health, i.e. they tend to rate their health as better than otherwise comparable younger respondents (Groot, 2000; Van Doorslaer \& Gerdtham, 2003). Most probably, this happens because health declines in general with age, so that the perception of what is "good health" also changes when individuals get older. The decrease of self-reported health in age measured in surveys thus tends to understate the decline in true health. Another example is socioeconomic status. The measurement of social inequalities in health can be severely biased if the response behaviour of rich and poor individuals differs. For example, many studies have shown that unemployment has a lasting effect on general life satisfaction (Winkelmann \& Winkelmann, 1998; Clark, Georgellis \& Sanfey, 2001). This might influence response behaviour in surveys, leading respondents to a more pessimistic view of their own health than they might otherwise have. If this is the case, effects of unemployment on health will be overstated.

The fundamental assumption behind this view is that there is such thing as a "true" and comparable health status. Conceptually, true health is considered as a continuous, latent (i.e., unobservable) variable. When respondents answer survey questions about their health, they assess their true health (possibly with measurement error; see Crossley \& Kennedy, 2002) and project this value onto the scale provided by the survey researcher. Equivalent econometric formulations are the ordered logit or probit models. It is the task of the researcher to "rescale" the respondents answers if response styles or reference points differ across individuals. This implies that one must be willing not to accept people's own judgements as absolute (Sen, 2002). The question that follows immediately is on which basis to rescale individual judgements.

A very recent attempt to design a common comparable scales (not only for health) is the anchoring vignette approach (King, Murray, Salomon \& Tandon, 2004). Vignettes are short descriptions of persons in different health states, which respondents are asked to judge on the same scale as they are asked to judge their own health. Respondents are explicitly asked to think about the vignette persons as people of their own age and background. The idea is thus that respondents put themselves in the shoes of the vignette persons. An example vignette for mobility is: "John is able to move his arms and legs, but requires assistance in standing up from a chair or walking around the house. Any bending or lifting is very difficult. How would you rate his mobility? Very good, good, moderate, bad, or very bad?" In a typical vignette 
study, respondents would be asked to answer 3 to 7 vignettes that describe different degrees of mobility, from marathon runners to quadriplegics. If responses are consistent across vignettes and self-ratings, i.e. if the same scale is used by the respondent, it is possible to recover the respondents' individual reference points. The main disadvantage of vignettes is that none have yet been developed for general health, i.e. the self-report measure that I examine in the present paper.

Another approach to rescale the respondent's answers is to use other, presumably more objective measures of health, e.g., the self-reported presence of chronic conditions, functional limitations, problems with activities of daily living, or (disability) weighted indices combining these dimensions (e.g. Groot, 2000; Lindeboom \& Van Doorslaer, 2003). To examine whether there is reporting bias, subjective health is regressed on objective health and the relevant covariates, possibly in interaction with the objective health measure. The coefficient of a covariate would tell us if certain types of individuals (e.g., men) tend to overstate or understate their health relative to other types of individuals.(e.g., women). If that is the case, one can carry the analysis further and calculate counterfactual health distributions. For instance, one can calculate how the health of men and women compares if we assume that men behave like women (at least when they answer surveys). However, the possibility that self-reports of chronic conditions are also subject to measurement error is often overlooked in studies of this kind (Baker, Stabile \& Deri, 2001).

The data used in the present study has only few contemporaneous quasi-objective measures of health, so that it is not possible to follow that approach. Technically, one could use future mortality as an objective health measure as a regressor. However, there are some obvious drawbacks: Right-censoring and sample attrition make mortality an unattractive right-hand side variable. About 20 percent of the sample is lost due to attrition between 1992 and 2003 and of the remaining cases, about 75 percent are right-censored. Both problems can be much more easily dealt with if mortality is put on the left hand side of the equation. I will thus confine the analysis to the estimation of duration models, regressing mortality on self-reported health, and a number of other relevant variables, such as age, sex, or income. Additional specifications will also include interaction effects between self-assessed health and the other covariates. 
If self-assessed health is an unbiased measure of health, other covariates should have only negligible independent effects on mortality. If a strong and significant effect of a covariate is found, this might indicate response bias with respect to that variable. For instance, a positive coefficient of some variable $\mathrm{X}$ on mortality, conditional on self-assessed health, indicates that respondents with high value of $\mathrm{X}$ die earlier than those with low values of $\mathrm{X}$. Put differently, individuals with high $\mathrm{X}$ tend to over-value their health compared to individuals with low $\mathrm{X}$. Thus the coefficient of $\mathrm{X}$ provides a measure of the response bias associated with $\mathrm{X}$. The basic assumption behind this interpretation is that there are no unobserved factors that are correlated with $\mathrm{X}$. This assumption is violated if, conditional on current self-reported health, future events are systematically linked to the explanatory variables. For example, men might have a higher probability to die from non-natural causes or to get a disease that kills fast (e.g. lung cancer or a heart attack). If the cause of death was known - which is not - it would be possible to test this assumption.

Although, the analysis in this paper is very similar to Van Doorslaer \& Gerdtham's (2003) analysis of the Swedish Survey of Living Conditions, there is one important difference in the interpretation of the results. Van Doorslaer \& Gerdtham do not interpret significant main effects of covariates as evidence for reporting bias and thus as a need to worry. For instance, they find significant main effects of income on mortality but no interaction effects between income and self-reported health and conclude: "The fact that the SAH effect does not seem to differ by SES indicators like income or education suggests that there is no systematic adjustment of SAH reporting by SES." (p.1628). The absence of an interaction effect means that being in good rather than fair health has always the same effect on mortality, no matter if you are rich or poor. In other words, the difference in true health between good and fair is the same for all income groups. But it does not mean that good and fair reflect the same levels of health for all income groups. The absence of interaction effects is not sufficient to conclude that comparability of self-assessed health across groups is unproblematic.

The paper is organised as follows. In the next section, I will give a brief description of the data and sample characteristics. Section 3 contains the empirical results. I first show how selfassessed health and mortality relate to the socio-economic characteristics of the respondents. Then I examine the relationship between these characteristics and mortality, conditional on self-assessed health. Strong conditional effects indicate substantial differences in response 
behaviour across socio-economic groups. Section 4 concludes with some recommendations for future research.

\section{Data}

The data are drawn from the years 1992 to 2003 of the SOEP, an ongoing panel survey of the German population. A detailed description is given by the SOEP Group (2001). Although the SOEP started in 1984, 1992 is the first year in which respondents were asked to self-assess general health on the 5-point "very good" to "very poor" scale. I restrict the sample to German respondents aged 50 and older. The guest worker sub-sample is excluded because many elderly returned to their home countries and thus dropped out of the SOEP. The sample consists of 4,048 individuals, of which 2,258 (55.3 percent) are women (see Table 1).

Date of death information up to 2001 is available either from the household interviews or from a special status check for drop-outs, in which the status of $90.2 \%$ of 7,902 drop-outs could be verified (720 respondents died, year of death is known for 718 respondents). The remaining 9.8 percent have either moved to an unknown new address or died. Unfortunately, the released data does not identify these observations, i.e. it is not possible to distinguish who dropped out of the SOEP and was still alive and who dropped out of the SOEP and whose status could not be verified. Only verified deaths are coded. Of the 4,048 observation in my sub-sample, 857 are drop-outs not coded as dead. These observations are treated as rightcensored at the time they leave the panel.

25 percent of the men and 21 percent of the women are dead in 2003. Another 21 percent left the sample for other reasons. The life expectancy of those who died between 1992 and 2003 was on average 5.5 years. The average age (in 1992) of the working sample is 62.9 years, with women being on average about two years older than men. Socio-economic status is measured by three variables: equivalised annual net household income (in quartiles), home ownership (as a crude measure of wealth), and schooling (less than high school, high school, and more than high school). The men in the sample have on average higher income and they live more often in owner-occupied housing than the women. One third of the sample are East Germans (they are over-sampled; note that all results presented in this paper are unweighted). Finally, I have generated a dummy variable for early retirement, which is 1 for all men who are younger than 63 and retired and all women who are younger than 60 and retired, and 0 for all others. 
$<$ about here Table 1>

Women are in worse self-assessed health than men. 34.6 percent of the men say that they are in good or very good health, whereas only 27.9 percent of the women do so. As in many other studies, women in the SOEP report worse health but they live longer. As mentioned before, there are only few variables in the SOEP that could be used as contemporaneous quasiobjective health measures, such as doctor visits, hospital stays, and disability status. The relationship between true health and reported health, conditional on these measures, is likely to be affected by our covariates. For example, women tend to go to doctors more often than men independent of their true health status. Richer people might be able to afford more doctor visits, better educated individuals might be more knowledgeable about health issues and thus visit doctors less often in case of minor illnesses, etc. Doctor visits are very much choice dependent, in contrast to hospital stays. The SOEP contains (retrospective) data on the number of hospital stays and the number of nights spent in hospital. However, these data are available only for 1991, not 1992. Still, I will use the number of hospital stays in 1991 as a proxy for objective health status. The proportion of respondents who have stayed in hospital at least for one day is about 14 percent. Roughly one half of these have stayed up to 14 nights. Sex differences in hospital stays are negligible.

\section{Results}

I begin by describing the relationship between the covariates and self-reported health one the one hand and mortality on the other hand. Columns 1 and 2 of Table 2 contain estimated odds ratios of a "naive" logit regression of being in poor or very poor self-assessed health on age, marital status, income, home ownership, education, region, early retirement, and hospital stays, separately for men and women. Drop-outs, i.e. respondents whose mortality status in 2003 is unknown have been dropped from these regressions. Odds ratios larger than one indicate decreasing self-assessed health. Note that the respondents' age enters the empirical model as a piecewise linear function. Age 1 measures the age effect in the 50 to 60 interval, Age 2 measures the age effect in the 60 to 75 interval, and Age 3 measures the age effect above age 75 . 
One purpose of this regression is to describe the differences in self-reported health status in the sample. According to the estimated model

- older respondents are less healthy than younger respondents

- married and unmarried respondents are equally healthy

- the poorest income quartile is the least healthy. Health differences across the remaining quartiles are comparatively small

- wealth (i.e. home ownership) has a weak and insignificant positive relationship with selfreported health.

- education has a strong positive and significant relation to self-reported health among men, but virtually no effect among women

- early retirees are muss less healthy than others

- East Germans are much healthier than West Germans

- short episodes of hospitalisation have only little effect on self-assessed health, whereas longer episodes have very large effects

$<$ about here Table $2>$

The main argument of this paper is that the results of this naive regression cannot be taken at face value. Columns 3 and 4 of Table 2 show odds ratios of logistic regression of being dead by 2003 on characteristics in 1992. Since mortality is an objective indicator of health, the effects of the covariates on mortality should not be much different from their effects on selfassessed health as a subjective measure. At least, they should have the same direction. Indeed, most results are consistent and in line with earlier studies, e.g. the positive correlation between income and wealth on the one side and self-assessed health as well as mortality on the other side. Still, there are some differences between both regressions that are worth being mentioned. First, mortality increases more steeply in age than self-reported health. This is illustrated in Figure 1, where I show predicted proportions of being in poor or very poor health and 11-year mortality by age in 1992. One interpretation of the differences slopes is that individuals get used to decreasing health when they age, so that their reference level for poor health changes. 
Further, it is unclear why East Germans report to be healthier than West Germans, although their life expectancy is about the same in the sample (in fact, it is lower in the population). The mortality of early retirees is only insignificantly larger than the mortality of others, which stands in contrast to their worse self-reports of health. One explanation for these results are differences in reporting behaviour between East and West Germans, or that self-reports of health are endogenous to labour market states.

The next step of the analysis is to estimate the life expectancy of different socio-economic groups conditional on their self-assessed health. Tables $3 \mathrm{a}$ and $3 \mathrm{~b}$ show the estimates of a discrete-time proportional hazard model with a non-parametrically specified baseline hazard (Jenkins, 1995; Prentice \& Gloeckler, 1978), separately for men and women. As mentioned above, respondents who leave the SOEP and whose status in 2003 is unknown are included in the analysis but coded as right-censored at the time of drop-out. Although possible with the available data, I do not let time-varying covariates (in particular: self-assessed health) vary in time. The reason is that I want to predict future mortality on the basis of the information available in 1992, i.e. on the basis of a single cross-section of data.

$<$ about here Tables $3 \mathrm{a}$ and $3 \mathrm{~b}>$

Tables $3 \mathrm{a}$ and $3 \mathrm{~b}$ contain the results of four different specifications, with and without selfrated health and with and without hospital stays. The reference category for self-assessed health is "fair", which is the middle category. Expectedly, self-assessed health has a strong effect on mortality (see column 2). For example, the hazard rate of a male respondent in very good health is only half as large as the hazard rate of a respondent in the reference category. The hazard rate of a male respondent in very poor health is 2.5 times as large as the hazard rate of someone in "fair" health. For women, the effects of poor and very poor health (compared to fair health) are quantitatively similar to men. However, the differences between those in good or very good health to those in fair health are smaller than for men and statistically insignificant.

$<$ about here Figure 2>

The variation of life expectancy by self-reported health and the sex differences in this variation are illustrated in Figure 2. It shows predicted survival rates for men and women with 
different self-reported health states and a fixed set of characteristics (West German, married, aged $70,2^{\text {nd }}$ income quartile, renter, high school education). For example, the 11-year survival rate of men in very good health was $73.2 \%$. It was $52.0 \%$ for men in fair health, and men in very poor health had a survival probability of only $20.5 \%$. Women in very good health had a survival probability of $81.1 \%$, compared to $74.6 \%$ if in fair health and $48.5 \%$ if in very poor health. Conditional on self-reported health, women live longer than men, but the difference is not uniform across the self-reported health distribution. There is a small difference between men and women in very good self-reported health and a large difference between men and women in very poor health. The distinction between very good and fair is more informative among men than among women. Moreover, it is statistically significant only among men.

$<$ about here Figure 3>

Figure 3 shows variations in life expectancy by the number of nights spent in hospital in 1991, keeping all other characteristics fixed. Again, conditional on the number of nights spent in hospital, women are less likely to die than men. Note that there is no difference between women who spent up to 14 nights in hospital and those who have not been hospitalised. One explanation for this finding would be that women's short episodes of hospitalisation are due to the treatment of non-lethal chronic diseases.

We now turn to the effects of the covariates. Unsurprisingly, age in 1992 has a positive effect on mortality, but it is interesting to note the difference between the sexes. Male mortality rates increases much faster in age between 50 and 60 than female mortality rates. Between age 60 and 75, the increase is about the same across the sexes and above the age of 75 , the increase in male mortality rates is slower then the increase in female mortality rates. These results suggest that much of the difference in mortality between men and women is due to health events in the life of 50 to 60 year olds.

Being married appears to be beneficial especially for men. In fact, the affect is quite large. One reason could be unobserved differences in risk factors (drinking, smoking, and diet) or other health behaviours (such as the likelihood of visiting a doctor conditional on being sick) associated with marital status. Another explanation could be a selection effect if healthier men are more likely to be married. However, as we have shown above, they were about as healthy at baseline (in 1992) as unmarried, divorced or widowed men. There is also a clear negative 
relationship between economic status (measured by equivalised household income in 1992 and home ownership) and mortality. The relationship is a bit weaker for women than for men. Education has a positive effect on survival at all ages. In particular those with less than high school education die earlier than others, but the effect is only weakly statistically significant.

Generally, a comparison of the models with and without self-reported health reveals that the coefficients of most covariates barely change when subjective health status or hospitalisation are included in the regression. The inclusion of subjective health usually attenuates the effect of other covariates, but including hospitalisation often has no influence at all on covariates' coefficients. Thus, even if we condition on self-reported health or hospitalisation, age, marital status and income continue to have explanatory power for mortality. This is especially true for men, although this is unlikely a genuine sex difference. If the sample is split further by age, it can be shown that economic status has a larger effect on mortality at young ages than at old ages (see e.g. Deaton \& Paxson 1998). Since women live longer, female mortality rates on average tend to be less affected by economic status than male mortality rates.

The finding that some covariates' effects to not vanish if subjective health is controlled for raises important questions. First, it could mean that self-assessed health is not comparable across different socio-economic groups. For example, the fact that, conditional on selfreported health, mortality increases quite sharply in age, suggests that older respondents tend to overstate their health relative to younger respondents. This happens because of habituation to poor health as one becomes older, i.e. because of a shift in the reference point. An alternative explanation would be cohort effects. It is possible that older cohorts are simply "complaining less" than younger cohorts. However, given the nature of our data, it is not possible to distinguish age and cohort effects.

Another example is economic status. The fact that rich respondents live longer (conditional on self-reported health) could be explained by a tendency to understate their health relative to poor respondents. This finding becomes relevant when social inequalities in health are analysed on the basis of self-reports. It is likely that inequalities will be understated. Further, the parameter of early retirement is interesting from an economic viewpoint. Several studies have examined whether self reports of health are endogenous to labour market states (Bound, 1991; Dwyer \& Mitchell, 1999). If respondents report to be in poor health partly to justify that they are in early retirement (justification bias), early retirees should survive longer, 
conditional on self-reported health. The results shown in Tables $3 \mathrm{a}$ and $3 \mathrm{~b}$ do not lend support to this assumption. It even seems as if early retirees slightly overstate their health (relative to others). However, the effect is not significant. Qualitatively similar results are obtained when the sample is restricted to respondents who in 1992 were younger than 65 .

So far, we have only looked at differences in levels (or health index shifts, in the language of Lindeboom and Van Doorslaer (2003)). A further question is whether the relationship between self-assessed health and mortality differs across groups. This can be assessed by estimating the above equations with interaction effects between health and other explanatory variables and test whether the interaction effects are jointly significant. For example, using Swedish data, Van Doorslaer and Gerdtham (2003) find larger gradients for women than for men, and for older than for younger respondents, but no interaction effects between income or education and self-assessed health.

For the sake of brevity, I omit detailed regression results and only show joint tests of interaction terms between self-assessed health and each of the covariates listed in Table 4. The null hypothesis of all interaction terms being equal to zero is rejected for three variables, each time only among women: age, income, and early retirement status. Note that it was not possible to compute an interaction effect of early retirement with self-reported health among early retired women. The model suffered from separation because all early retired women in very good health survived.

$<$ about here Table 4>

Significant interaction effects are illustrated in Figures 4 to 6 . For those variables where I found significant interaction effects among women, I also show the (generally insignificant) interaction effects for men. The figures show predicted survival rates relative to respondents in fair health (who are thus represented by the horizontal line at 1). Differences across subgroups, e.g. young and old respondents, in the effect of specific subjective health states on survival rates are thus differences in relative risks.

Figures $4 \mathrm{a}$ and $4 \mathrm{~b}$ show the survival rates for 55 year old ("young") and 75 year old ("old") men and women, respectively. Among young respondents, the differences in survival rates between those in very good and those in fair health are small and statistically insignificant. 
Only men who report poor or very poor health are less likely to survive at all ages. Among older men, there is a further difference in survival rates between those in very good and those in fair health. However, although the difference is large in size it is statistically insignificant simply because the number of old men in very good health is very small. As their male counterparts, 55-year old women in very poor health are less likely to survive than those in fair or better health. However, the survival probability of younger women in poor health is only slightly smaller than the survival probability of those in fair or better health. This changes when women become older. At age 75, the largest survival gap is between women in poor and very poor health on the one side and women in fair or better health on the other side. The interaction affect between health and age is basically this change in the (substantive) significance of poor self-reported health for survival.

Overall, relative survival differences between individuals of different self-reported health increase in age. These results can be interpreted as evidence that true health differences between young respondents of different self-assessed health levels are smaller than true health differences between older respondents. In fact, as far as mortality is concerned, the distinction between very good, good, and fair is more or less meaningless among the young.

$<$ about here Figures 4 to $6>$

Figures $5 \mathrm{a}$ and $5 \mathrm{~b}$ show interaction effects of self-reported health with income by comparing predicted survival rates of 70 year old men and women with income below and above the median, respectively. Statistically, the mortality gap between rich and poor men in different health states is insignificant. The only visible difference between rich and poor men in relative survival is among the few respondents in very good health. In contrast to men, interaction effects for women are statistically significant. First, being in very good health has no positive effect on survival among the rich. Second, poor and very poor health have about the same effect on mortality among poorer women. Among richer women, the relative effect of poor health is smaller.

Finally, Figures $6 \mathrm{a}$ and $6 \mathrm{~b}$ show the interaction effects of early retirement and self-assessed health for 60 year old men and women, respectively. As explained above, the model estimated for women suffers from complete separation. Hence I omit survival rates for respondents in very good health. Again, we cannot see much difference in relative survival rates among early 
retired men and their non-retired counterparts. However, early retired women in very poor health are much less likely to survive than non-retirees - relative to the counterparts in fair health.

\section{Discussion}

This paper examines the structure of the relationship between self-assessed general health and subsequent mortality among respondents aged 50 and over using data from the German SocioEconomic Panel. In general, self-assessed health proves to be a strong predictor of mortality. However, conditional on self-assessed health, other covariates such as sex, age, or income still have strong independent effects on mortality, which are often similar in size to their unconditional effects. This should not be case if self-assessed health was a valid and unbiased proxy measure for true health. Rather, self-assessed health should absorb many of the health risks associated with these covariates.

The use of self-assessed health as a proxy for true health can thus give rise to misleading inferences about social inequalities in health or the effects of health on retirement, health care use, etc. Whether that is the case depends on the reason for the independent effects of age, sex, or income on mortality. There are two complementary explanations. First, lethal events that are unexpected and uncorrelated with current health might vary systematically by these covariates. If that is the case, no harm is done, because we can still assume that self-reports reflect true health. For example, if men are more likely to be killed in a car accident, they will have a higher mortality, independent of their true health status. The question is whether such events are frequent enough to explain the mortality gap between equally healthy men and women. Information on chronic conditions or cause of death would be of great help to answer this question (Case \& Paxson, 2004). Another example is the effect of income or wealth. A wealthy person who is in the same true health status as a poor person might be able to "buy time", for example because she can afford better treatment and thus increase her lifeexpectancy. However, the public health systems in many European countries, including Germany, are so generous that, conditional on true health, wealth should not matter much for life expectancy.

The second - more damaging - explanation is that response behaviour differs across different groups, i.e. individuals with the same true health status have different reference points against 
which they judge their health. Respondents do not perceive the self-assessed health scale as absolute. They may be likely to report "very poor" health only if they feel they are much less healthy than others of the same sex, age, education, or income. In fact, some surveys (e.g., the BHPS) take that into account when they ask respondents to rate their health relative to other people of their own age. The fact that self-rated health increases in age in the BHPS, conditional on a number of quasi-objective measures, is strong support for the shifting reference point explanation (Groot, 2000). A related argument that applies to cross-cultural comparisons of health refers to differences in habitual language use. For instance, "excellent" is a term that is used in everyday parlance in the Anglo-Saxon world, but Germans would often consider this attribute as an ironic exaggeration. Objective health measures and maybe vignettes are needed to ascertain the relevance of response styles.

What are the implications of the findings of the present and other studies for empirical research on the causes and consequences of health? It is quite likely that self-assessed health is comparable only within narrowly defined socio-economic groups. This suggest to use subjective health measures only in within-subsample analyses. Apart from likely problems with small sample sizes, it is yet unclear which characteristics should be used to split the sample. Sex and age are the most likely candidates, but beyond that there appears to be no generally accepted set of variables. Moreover, the restriction to different subsamples precludes to answer interesting research questions across subgroups.

A more promising option is to make self-assessed health comparable across groups on the basis of specialised health surveys that provide subjective and objective measures of health (and possibly vignettes). This appears to be self-evident in cross-national research, but it surely will also help to improve analyses using national surveys. 


\section{References}

Baker, M., Stabile, M. \& Deri, C. (2001): What do self-reported, objective, measures of health measure? NBER Working Paper 8419.

Benyamini Y. \& Idler E.L. (1999): Community Studies Reporting Association Between SelfRated Health and Mortality: Additional Studies, 1995 to 1998. Research On Aging 21, 392-401.

Bound, J. (1991): Self-Reported versus Objective Measures of Health in Retirement Models. Journal of Human Resources 26, 106-138.

Case, A. \& Paxson, C. (2004): Sex differences in morbidity and mortality. NBER working paper 10653.

Clark, A.E., Georgellis, Y. \& Sanfey, P. (2001): Scarring: the psychological impact of past unemployment. Economica 68, 221-241.

Crossley, T. \& Kennedy, S. (2002): The reliability of self-assessed health status. Journal of Health Economics 21, 643-658.

Cutler, D.M. \& Richardson, E. (1997): Measuring the Health of the U.S. population. Brookings Papers on Economic Activity: Microeconomics 1997, 217-271.

Deaton, A. \& Paxson, C. (1998): Aging and Inequality in Health and Income. American Economic Review 88, 248-253.

Dwyer, D.S. \& Mitchell, O.S. (1999): Health problems as determinants of retirement: are selfrated measures endogenous? Journal of Health Economics 18, 173-193.

Groot, W. (2000): Adaption and scale of reference bias in self-assessments of quality of life. Journal of Health Economics 19, 403-420.

Idler, E.L. \& Benyamini, Y. (1997): Self-rated health and mortality: A review of twentyseven community studies. Journal of Health and Social Behavior 38, 21-37.

Jenkins, S. (1995): Easy Estimation Methods for Discrete-Time Duration Models. Oxford Bulletin of Economics and Statistics 57, 129-138.

King, G., Murray, C.J., Salomon, J.A. \& Tandon, A. (2004): Enhancing the Validity and Cross-Cultural Comparability of Measurement in Survey Research. American Political Science Review 98, 191-207.

Lindeboom, M. \& Van Doorslaer, E. (2003): Cut-point shift and index shift in self-reported health. Tinbergen Institute Discussion Paper TI 2003-042/3.

Prentice, R. \& Gloeckler L. (1978). Regression analysis of grouped survival data with application to breast cancer data. Biometrics 34, 57-67.

Schwarze, J., Andersen, H.A. \& Anger, S. (2000): Self-rated health and changes in self-rated health as predictors of mortality. First evidence from German panel data. DIW Discussion Paper 203.

Sen, A. (2002): Health: perception versus observation. British Medical Journal 324, 860-861.

SOEP Group (2001): The German Socio-Economic Panel (SOEP) after more than 15 years Overview. Vierteljahreshefte zur Wirtschaftsforschung 70, 7-14.

Van Doorslaer, E. \& Gerdtham, U.-G. (2003): Does inequality in self-assessed health predict inequality in survival by income? Evidence from Swedish Data. Social Science \& Medicine 57, 1621-1629. 
Winkelmann, L. \& R. Winkelmann, 1998, Why are the unemployed so unhappy? Economica $65,1-15$. 
Table 1: Sample Description

\begin{tabular}{|c|c|c|c|}
\hline Variable & Total & Men & Women \\
\hline Dead in 2003 & .231 & .254 & .213 \\
\hline Drop-outs & .210 & .193 & .224 \\
\hline Survival years ${ }^{\text {a) }}$ & 5.48 & 5.25 & 5.70 \\
\hline \multicolumn{4}{|l|}{ Characteristics as of 1992} \\
\hline Female & .553 & 0 & 1 \\
\hline Married & .714 & .860 & .596 \\
\hline Age & 62.9 & 61.7 & 63.8 \\
\hline First income quartile & .252 & .192 & .300 \\
\hline Second income quartile & .249 & .237 & .258 \\
\hline Third income quartile & .250 & .273 & .231 \\
\hline Fourth income quartile & .250 & .298 & .211 \\
\hline Home ownership & .512 & .547 & .483 \\
\hline Education: less than high school & .272 & .098 & .413 \\
\hline Education: high school & .612 & .729 & .518 \\
\hline Education: more than high school & .115 & .174 & .068 \\
\hline Early Retirement & .108 & .158 & .067 \\
\hline East Germany & .340 & .342 & .339 \\
\hline \multicolumn{4}{|l|}{ Self-Assessed Health in 1992} \\
\hline Very good health & .045 & .048 & .043 \\
\hline Good health & .264 & .298 & .236 \\
\hline Fair health & .426 & .412 & .437 \\
\hline Poor health & .187 & .167 & .203 \\
\hline Very poor health & .079 & .075 & .082 \\
\hline \multicolumn{4}{|l|}{ Nights in hospital in 1991} \\
\hline 0 & .862 & .860 & .864 \\
\hline 1 to 14 & .065 & .063 & .067 \\
\hline 15 to 35 & .044 & .046 & .043 \\
\hline 36 and more & .029 & .031 & .026 \\
\hline $\mathrm{N}$ & 4,048 & 1,826 & 2,258 \\
\hline
\end{tabular}

Note - a) conditional on being dead in 2003; Source: SOEP 1992-2003 
Table 2: Logistic regressions of being in poor or very poor health and 11-year mortality, by sex

\begin{tabular}{|c|c|c|c|c|}
\hline & \multicolumn{2}{|c|}{ Self-assessed health } & \multicolumn{2}{|c|}{ Mortality } \\
\hline & Men & Women & Men & Women \\
\hline \multirow[t]{2}{*}{ Age1 $[\min ($ Age, 60$)]$} & 1.005 & 1.040 & $1.117 * *$ & 1.052 \\
\hline & $(0.028)$ & $(0.025)$ & $(0.035)$ & $(0.035)$ \\
\hline \multirow[t]{2}{*}{ Age $2[\max (\min ($ Age, 75$), 60)-60]$} & $1.062 * *$ & $1.039 *$ & $1.127 * *$ & $1.133 * *$ \\
\hline & $(0.020)$ & $(0.016)$ & $(0.022)$ & $(0.021)$ \\
\hline \multirow{2}{*}{ Age3 [max (Age, 75) - 75] } & $1.050+$ & $1.051 *$ & $1.211 * *$ & $1.254 * *$ \\
\hline & $(0.031)$ & $(0.023)$ & $(0.063)$ & $(0.044)$ \\
\hline \multirow{2}{*}{ Married } & 1.057 & 1.082 & $0.614^{*}$ & 1.020 \\
\hline & $(0.199)$ & $(0.143)$ & $(0.117)$ & $(0.155)$ \\
\hline Income: $1^{\text {st }}$ quartile & 1.000 & 1.000 & 1.000 & 1.000 \\
\hline \multirow{2}{*}{ Income: $2^{\text {nd }}$ quartile } & $0.671^{*}$ & $0.749+$ & 0.741 & 0.821 \\
\hline & $(0.133)$ & $(0.114)$ & $(0.147)$ & $(0.143)$ \\
\hline \multirow[t]{2}{*}{ Income: $3^{\text {rd }}$ quartile } & $0.677+$ & $0.600 * *$ & $0.606^{*}$ & $0.510 * *$ \\
\hline & $(0.144)$ & $(0.105)$ & $(0.133)$ & $(0.107)$ \\
\hline \multirow[t]{2}{*}{ Income: $4^{\text {th }}$ quartile } & 0.693 & $0.605^{*}$ & $0.445 * *$ & $0.431 * *$ \\
\hline & $(0.163)$ & $(0.118)$ & $(0.109)$ & $(0.105)$ \\
\hline \multirow[t]{2}{*}{ Home ownership } & 0.816 & 0.897 & $0.758^{*}$ & 0.958 \\
\hline & $(0.111)$ & $(0.106)$ & $(0.107)$ & $(0.136)$ \\
\hline \multirow[t]{2}{*}{ Less than high school } & $1.877 * *$ & 1.157 & $1.464+$ & $1.348^{*}$ \\
\hline & $(0.373)$ & $(0.141)$ & $(0.313)$ & $(0.194)$ \\
\hline High School & 1.000 & 1.000 & 1.000 & 1.000 \\
\hline \multirow[t]{2}{*}{ More than high school } & 0.800 & 0.946 & 0.755 & 0.939 \\
\hline & $(0.155)$ & $(0.227)$ & $(0.153)$ & $(0.284)$ \\
\hline \multirow[t]{2}{*}{ Early Retiree } & $1.894 * *$ & $2.231 * *$ & 1.239 & 1.441 \\
\hline & $(0.378)$ & $(0.496)$ & $(0.251)$ & $(0.420)$ \\
\hline \multirow[t]{2}{*}{ East Germany } & $0.653^{*}$ & $0.646^{* *}$ & 0.839 & 0.970 \\
\hline & $(0.116)$ & $(0.096)$ & $(0.152)$ & $(0.167)$ \\
\hline Nights in hospital: 0 & 1.000 & 1.000 & 1.000 & 1.000 \\
\hline \multirow[t]{2}{*}{ Nights in hospital: 1 to 14} & 1.402 & 1.235 & 1.345 & 0.944 \\
\hline & $(0.343)$ & $(0.270)$ & $(0.355)$ & $(0.257)$ \\
\hline \multirow[t]{2}{*}{ Nights in hospital: 15 to 35} & $3.821 * *$ & $4.257 * *$ & $2.094 * *$ & $1.921 *$ \\
\hline & $(0.962)$ & $(1.038)$ & $(0.581)$ & $(0.536)$ \\
\hline \multirow[t]{2}{*}{ Nights in hospital: more than 35} & $13.459 * *$ & $6.808 * *$ & $5.625 * *$ & $5.227 * *$ \\
\hline & $(5.052)$ & $(2.325)$ & $(2.080)$ & $(1.998)$ \\
\hline Observations & 1,460 & 1,734 & 1,460 & 1,734 \\
\hline Mean dependent variable & 0.252 & 0.296 & 0.314 & 0.273 \\
\hline
\end{tabular}


Table 3a: Discrete-time proportional hazards model of men's mortality, exponential form

\begin{tabular}{|c|c|c|c|c|}
\hline & (1) & (2) & (3) & (4) \\
\hline Age1 [min(Age, 60)] & $\begin{array}{l}1.126^{* *} \\
(0.030)\end{array}$ & $\begin{array}{l}1.127^{* *} \\
(0.030)\end{array}$ & $\begin{array}{l}1.123^{* *} \\
(0.031)\end{array}$ & $\begin{array}{l}1.125^{* *} \\
(0.031)\end{array}$ \\
\hline Age2 $[\max (\min ($ Age, 75$), 60)-60]$ & $\begin{array}{l}1.095 * * \\
(0.014)\end{array}$ & $\begin{array}{l}1.082 * * \\
(0.014)\end{array}$ & $\begin{array}{l}1.090 * * \\
(0.014)\end{array}$ & $\begin{array}{l}1.080^{* *} \\
(0.014)\end{array}$ \\
\hline Age3 [max $($ Age, 75$)-75]$ & $\begin{array}{l}1.064 * * \\
(0.017)\end{array}$ & $\begin{array}{l}1.061^{* *} \\
(0.017)\end{array}$ & $\begin{array}{l}1.071^{* *} \\
(0.018)\end{array}$ & $\begin{array}{l}1.064^{* *} \\
(0.018)\end{array}$ \\
\hline Married & $\begin{array}{r}0.730^{*} \\
(0.090)\end{array}$ & $\begin{array}{l}0.679 * * \\
(0.082)\end{array}$ & $\begin{array}{l}0.721 * * \\
(0.090)\end{array}$ & $\begin{array}{l}0.682^{* *} \\
(0.083)\end{array}$ \\
\hline Income: $1^{\text {st }}$ quartile & 1.000 & 1.000 & 1.000 & 1.000 \\
\hline Income: $2^{\text {nd }}$ quartile & $\begin{array}{c}0.812 \\
(0.108)\end{array}$ & $\begin{array}{c}0.857 \\
(0.115)\end{array}$ & $\begin{array}{c}0.837 \\
(0.111)\end{array}$ & $\begin{array}{c}0.869 \\
(0.116)\end{array}$ \\
\hline Income: $3^{\text {rd }}$ quartile & $\begin{array}{l}0.672 * * \\
(0.101)\end{array}$ & $\begin{array}{l}0.716^{*} \\
(0.108)\end{array}$ & $\begin{array}{r}0.682 * \\
(0.102)\end{array}$ & $\begin{array}{r}0.707^{*} \\
(0.106)\end{array}$ \\
\hline Income: $4^{\text {th }}$ quartile & $\begin{array}{l}0.507 * * \\
(0.089)\end{array}$ & $\begin{array}{l}0.573 * * \\
(0.102)\end{array}$ & $\begin{array}{l}0.530 * * \\
(0.092)\end{array}$ & $\begin{array}{l}0.584^{* *} \\
(0.103)\end{array}$ \\
\hline Home owner & $\begin{array}{c}0.830+ \\
(0.082)\end{array}$ & $\begin{array}{c}0.865 \\
(0.086)\end{array}$ & $\begin{array}{c}0.828+ \\
(0.082)\end{array}$ & $\begin{array}{c}0.859 \\
(0.085)\end{array}$ \\
\hline Less than high school & $\begin{array}{c}1.308+ \\
(0.191)\end{array}$ & $\begin{array}{l}1.207 \\
(0.177)\end{array}$ & $\begin{array}{r}1.450^{*} \\
(0.214)\end{array}$ & $\begin{array}{c}1.316+ \\
(0.196)\end{array}$ \\
\hline High School & 1.000 & 1.000 & 1.000 & 1.000 \\
\hline More than high school & $\begin{array}{c}0.847 \\
(0.125)\end{array}$ & $\begin{array}{c}0.872 \\
(0.129)\end{array}$ & $\begin{array}{c}0.864 \\
(0.127)\end{array}$ & $\begin{array}{c}0.873 \\
(0.129)\end{array}$ \\
\hline Early Retiree & $\begin{array}{c}1.108 \\
(0.189)\end{array}$ & $\begin{array}{c}1.044 \\
(0.177)\end{array}$ & $\begin{array}{l}1.096 \\
(0.188)\end{array}$ & $\begin{array}{c}1.048 \\
(0.179)\end{array}$ \\
\hline East Germany & $\begin{array}{c}0.799+ \\
(0.102)\end{array}$ & $\begin{array}{c}0.810+ \\
(0.104)\end{array}$ & $\begin{array}{c}0.882 \\
(0.114)\end{array}$ & $\begin{array}{c}0.873 \\
(0.113)\end{array}$ \\
\hline Health: very good & & $\begin{array}{c}0.503+ \\
(0.195)\end{array}$ & & $\begin{array}{c}0.523+ \\
(0.203)\end{array}$ \\
\hline Health: good & & $\begin{array}{c}0.726^{*} \\
(0.100)\end{array}$ & & $\begin{array}{c}0.769+ \\
(0.107)\end{array}$ \\
\hline Health: fair & & 1.000 & & 1.000 \\
\hline Health: poor & & $\begin{array}{c}1.481 * * \\
(0.185)\end{array}$ & & $\begin{array}{c}1.358^{*} \\
(0.173)\end{array}$ \\
\hline Health: very poor & & $\begin{array}{l}2.518^{* *} \\
(0.343)\end{array}$ & & $\begin{array}{l}2.262^{* *} \\
(0.316)\end{array}$ \\
\hline Nights in hospital: 0 & & & 1.000 & 1.000 \\
\hline Nights in hospital: 1 to 14 & & & $\begin{array}{l}1.566^{* *} \\
(0.272)\end{array}$ & $\begin{array}{c}1.301 \\
(0.234)\end{array}$ \\
\hline Nights in hospital: 15 to 35 & & & $\begin{array}{l}1.834 * * \\
(0.310)\end{array}$ & $\begin{array}{l}1.575^{* *} \\
(0.269)\end{array}$ \\
\hline Nights in hospital: more than 35 & & & $\begin{array}{l}3.163^{* *} \\
(0.581)\end{array}$ & $\begin{array}{l}2.226^{* *} \\
(0.426)\end{array}$ \\
\hline Year dummies & yes & yes & yes & yes \\
\hline Observations & 14,882 & 14,882 & 14,882 & 14,882 \\
\hline
\end{tabular}

Note - Standard errors in parentheses $+\mathrm{p}<0.10 ; * \mathrm{p}<0.05 ; * * \mathrm{p}<0.01$ 
Table 3b: Discrete-time proportional hazards model of women's mortality, exponential form

\begin{tabular}{|c|c|c|c|c|}
\hline & $(1)$ & (2) & (3) & (4) \\
\hline Age1 $[\min ($ Age, 60$)]$ & $\begin{array}{l}1.057+ \\
(0.032)\end{array}$ & $\begin{array}{c}1.052 \\
(0.032)\end{array}$ & $\begin{array}{c}1.057+ \\
(0.032)\end{array}$ & $\begin{array}{c}1.052+ \\
(0.032)\end{array}$ \\
\hline Age2 $[\max (\min ($ Age, 75$), 60)-60]$ & $\begin{array}{l}1.103 * * \\
(0.015)\end{array}$ & $\begin{array}{l}1.099 * * \\
(0.015)\end{array}$ & $\begin{array}{l}1.099^{* *} \\
(0.015)\end{array}$ & $\begin{array}{l}1.096^{* *} \\
(0.015)\end{array}$ \\
\hline Age3 [max (Age, 75) - 75] & $\begin{array}{l}1.145^{* *} \\
(0.016)\end{array}$ & $\begin{array}{l}1.128 * * \\
(0.016)\end{array}$ & $\begin{array}{l}1.148^{* *} \\
(0.016)\end{array}$ & $\begin{array}{l}1.133^{* *} \\
(0.016)\end{array}$ \\
\hline Married & $\begin{array}{c}0.959 \\
(0.110)\end{array}$ & $\begin{array}{c}0.916 \\
(0.105)\end{array}$ & $\begin{array}{c}0.972 \\
(0.112)\end{array}$ & $\begin{array}{c}0.923 \\
(0.106)\end{array}$ \\
\hline Income: $2^{\text {nd }}$ quartile & $\begin{array}{c}0.855 \\
(0.104)\end{array}$ & $\begin{array}{c}0.977 \\
(0.122)\end{array}$ & $\begin{array}{c}0.825 \\
(0.100)\end{array}$ & $\begin{array}{c}0.923 \\
(0.115)\end{array}$ \\
\hline Income: $3^{\text {rd }}$ quartile & $\begin{array}{l}0.626^{* *} \\
(0.094)\end{array}$ & $\begin{array}{r}0.717^{*} \\
(0.109)\end{array}$ & $\begin{array}{l}0.596^{* *} \\
(0.089)\end{array}$ & $\begin{array}{l}0.673 * * \\
(0.103)\end{array}$ \\
\hline Income: $4^{\text {th }}$ quartile & $\begin{array}{l}0.563 * * \\
(0.107)\end{array}$ & $\begin{array}{c}0.661 * \\
(0.128)\end{array}$ & $\begin{array}{l}0.573 * * \\
(0.109)\end{array}$ & $\begin{array}{c}0.659 * \\
(0.127)\end{array}$ \\
\hline Home owner & $\begin{array}{c}0.952 \\
(0.097)\end{array}$ & $\begin{array}{c}0.975 \\
(0.100)\end{array}$ & $\begin{array}{c}0.954 \\
(0.097)\end{array}$ & $\begin{array}{c}0.969 \\
(0.100)\end{array}$ \\
\hline Less than high school & $\begin{array}{c}1.196+ \\
(0.122)\end{array}$ & $\begin{array}{l}1.158 \\
(0.119)\end{array}$ & $\begin{array}{c}1.174 \\
(0.121)\end{array}$ & $\begin{array}{c}1.142 \\
(0.118)\end{array}$ \\
\hline High school & 1.000 & 1.000 & 1.000 & 1.000 \\
\hline More than high school & $\begin{array}{c}1.059 \\
(0.254)\end{array}$ & $\begin{array}{c}1.032 \\
(0.248)\end{array}$ & $\begin{array}{c}0.987 \\
(0.239)\end{array}$ & $\begin{array}{c}0.965 \\
(0.234)\end{array}$ \\
\hline Early Retiree & $\begin{array}{c}1.343 \\
(0.364)\end{array}$ & $\begin{array}{c}1.210 \\
(0.328)\end{array}$ & $\begin{array}{c}1.378 \\
(0.374)\end{array}$ & $\begin{array}{c}1.248 \\
(0.339)\end{array}$ \\
\hline East Germany & $\begin{array}{c}0.949 \\
(0.112)\end{array}$ & $\begin{array}{c}1.025 \\
(0.122)\end{array}$ & $\begin{array}{c}0.934 \\
(0.110)\end{array}$ & $\begin{array}{c}0.999 \\
(0.119)\end{array}$ \\
\hline Health: very good & & $\begin{array}{c}0.759 \\
(0.277)\end{array}$ & & $\begin{array}{c}0.779 \\
(0.284)\end{array}$ \\
\hline Health: good & & $\begin{array}{c}0.812 \\
(0.127)\end{array}$ & & $\begin{array}{c}0.822 \\
(0.128)\end{array}$ \\
\hline Health: fair & & 1.000 & & 1.000 \\
\hline Health: poor & & $\begin{array}{l}1.412 * * \\
(0.167)\end{array}$ & & $\begin{array}{c}1.339 * \\
(0.160)\end{array}$ \\
\hline Health: very poor & & $\begin{array}{l}2.479 * * \\
(0.351)\end{array}$ & & $\begin{array}{l}2.201 * * \\
(0.320)\end{array}$ \\
\hline Nights in hospital: 1 to 14 & & & $\begin{array}{c}0.898 \\
(0.172)\end{array}$ & $\begin{array}{c}0.816 \\
(0.158)\end{array}$ \\
\hline Nights in hospital: 15 to 35 & & & $\begin{array}{l}2.070 * * \\
(0.359)\end{array}$ & $\begin{array}{l}1.703 * * \\
(0.303)\end{array}$ \\
\hline Nights in hospital: more than 35 & & & $\begin{array}{l}2.821 * * \\
(0.557)\end{array}$ & $\begin{array}{l}2.205^{* *} \\
(0.446)\end{array}$ \\
\hline Year dummies & yes** & yes** & yes** & yes** \\
\hline Observations & 18,764 & 18,764 & 18,764 & 18,764 \\
\hline
\end{tabular}

Note - Standard errors in parentheses $+\mathrm{p}<0.10 ; * \mathrm{p}<0.05 ; * * \mathrm{p}<0.01$ 
Table 4: Interaction effects of self-reported health with covariates, Chi-squared test statistics

\begin{tabular}{|c|c|c|c|c|c|c|}
\hline & \multicolumn{3}{|c|}{ Men } & \multicolumn{3}{|c|}{ Women } \\
\hline & $\begin{array}{c}\text { Chi- } \\
\text { Squared }\end{array}$ & $\mathrm{DF}$ & p-value & $\begin{array}{c}\text { Chi- } \\
\text { Squared }\end{array}$ & DF & p-value \\
\hline Sex & 0.58 & 4 & 0.965 & & & \\
\hline Age & 3.48 & 4 & 0.481 & 10.2 & 4 & 0.037 \\
\hline Married & 2.66 & 4 & 0.616 & 2.88 & 4 & 0.579 \\
\hline Income (below vs. above median) & 5.16 & 4 & 0.271 & 9.51 & 4 & 0.050 \\
\hline Home ownership & 3.51 & 4 & 0.477 & 1.34 & 4 & 0.855 \\
\hline Education (high school and above) & 2.72 & 4 & 0.606 & 1.06 & 4 & 0.900 \\
\hline Early retirement & 0.61 & 4 & 0.962 & 7.73 & $3^{\text {a) }}$ & 0.052 \\
\hline East Germany & 0.58 & 4 & 0.965 & 1.28 & 4 & 0.865 \\
\hline
\end{tabular}

Note $-{ }^{\text {a) }}$ One category predicted failure prefectly 


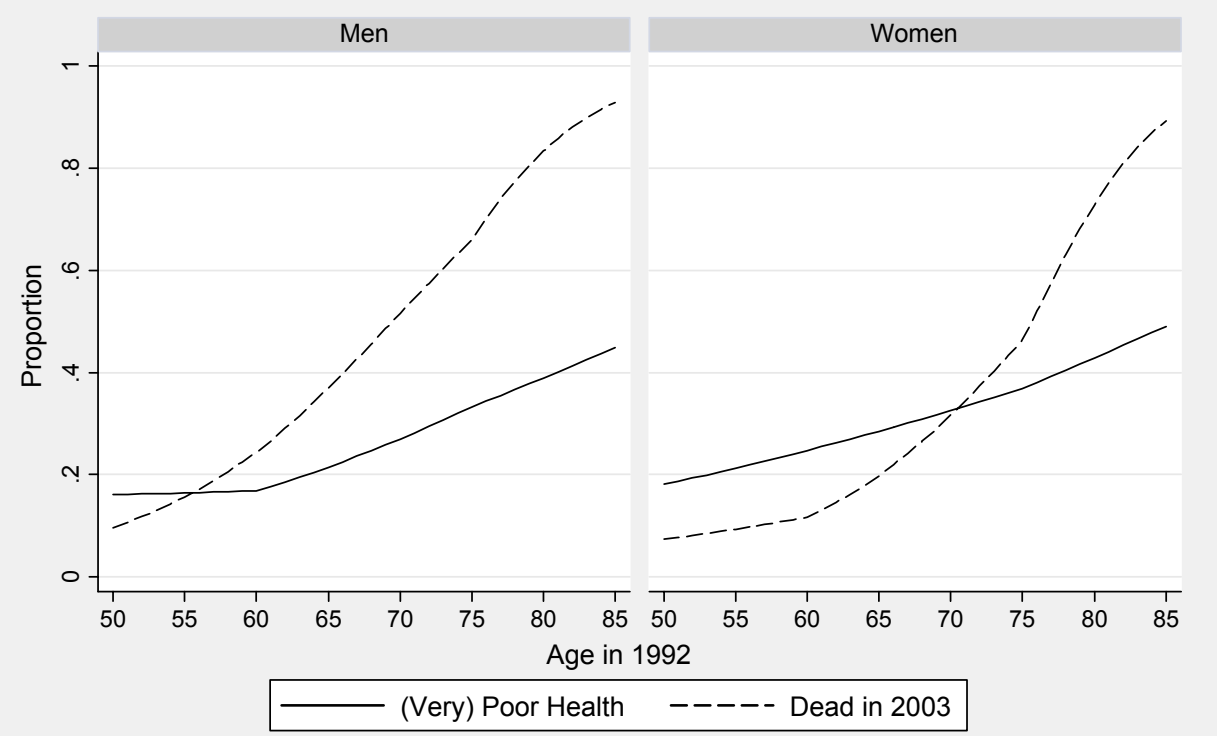

Figure 1: Predicted proportion of respondents in poor or very poor health and predicted 11year mortality (by sex).

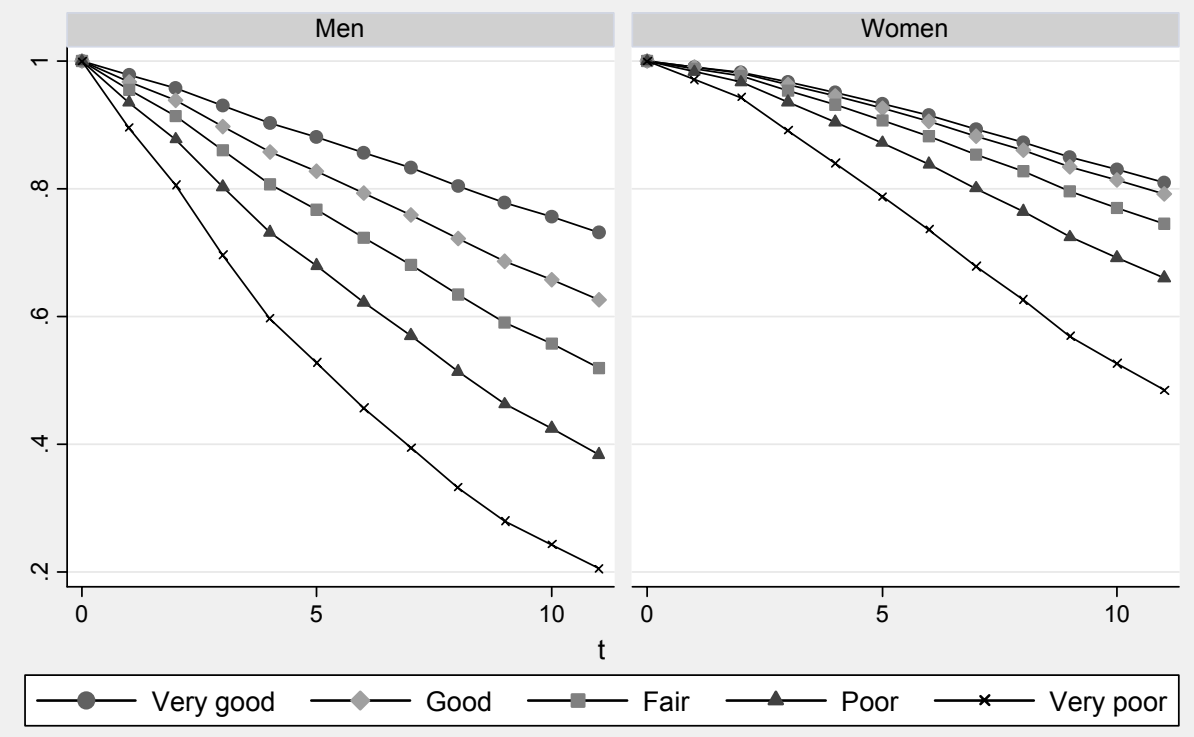

Figure 2: Predicted survival rates of 70 year olds, by sex and self-reported health (Source: SOEP 1992-2003) 


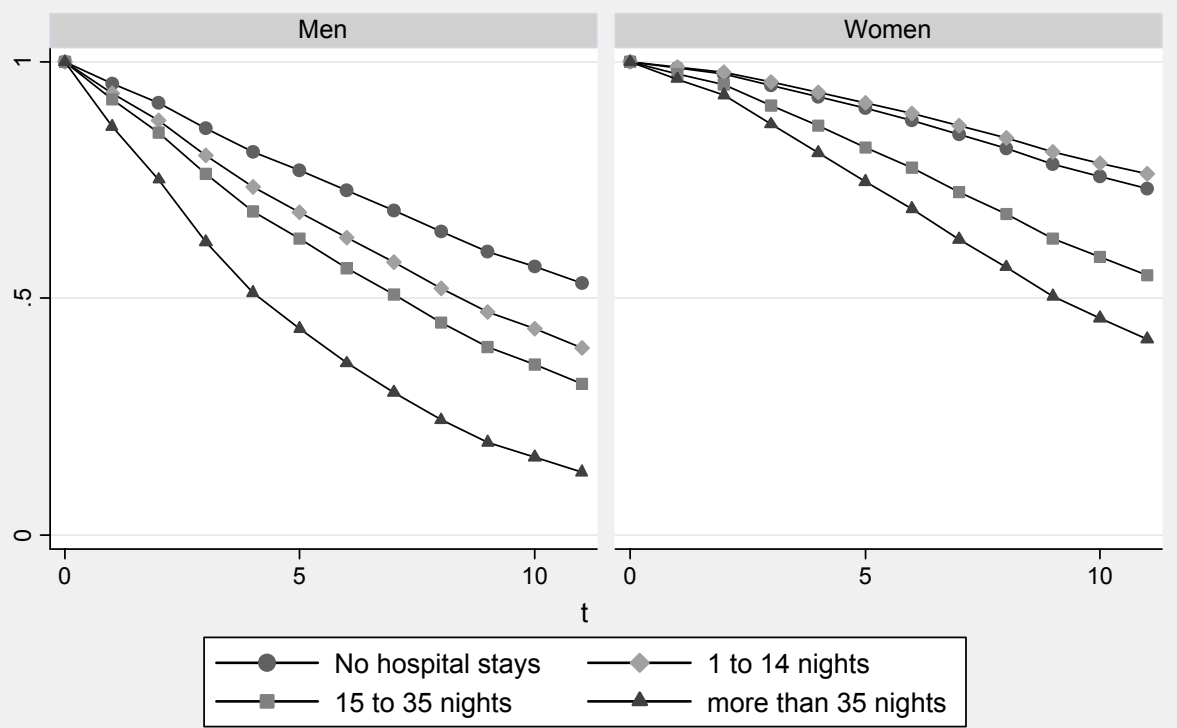

Figure 3: Predicted survival rates of 70 year olds, by sex and hospitalisation (Source: SOEP 1992-2003) 


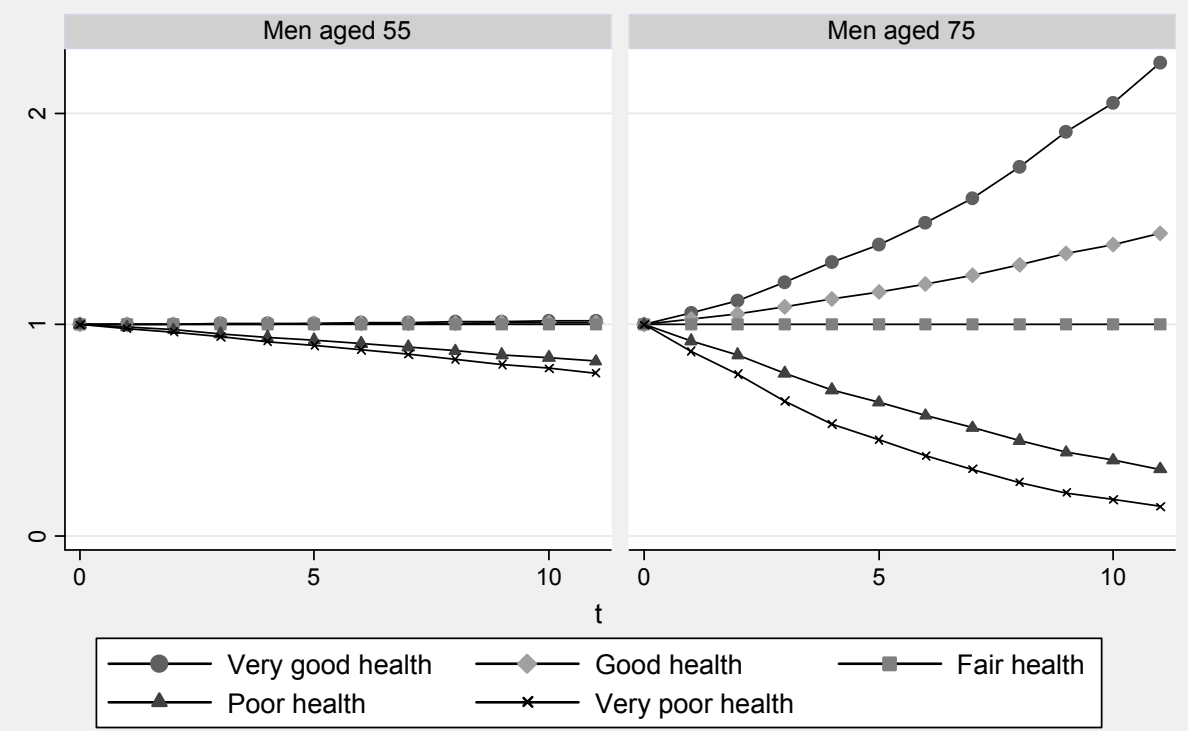

Figure 4a: Interaction effects of self-assessed health and age on predicted survival rates of men (Source: SOEP 1992-2003)

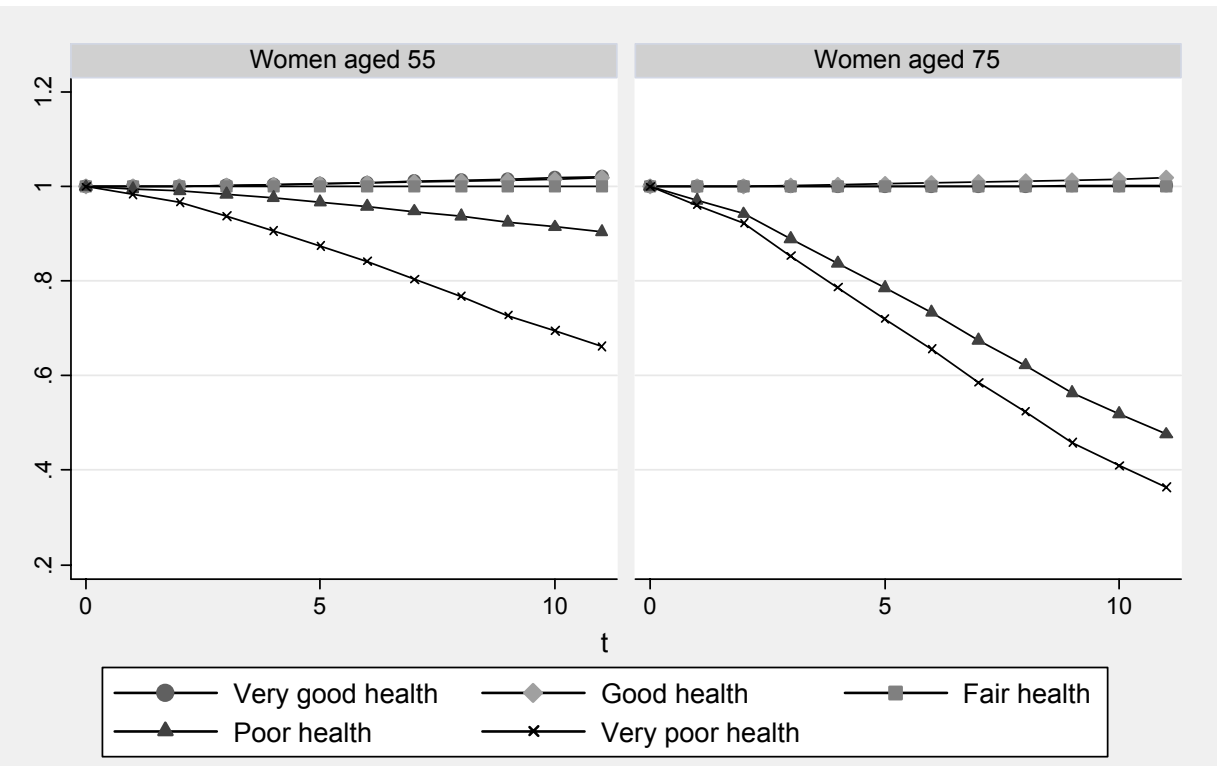

Figure 4b: Interaction effects of self-assessed health and age on predicted survival rates of women (Source: SOEP 1992-2003) 


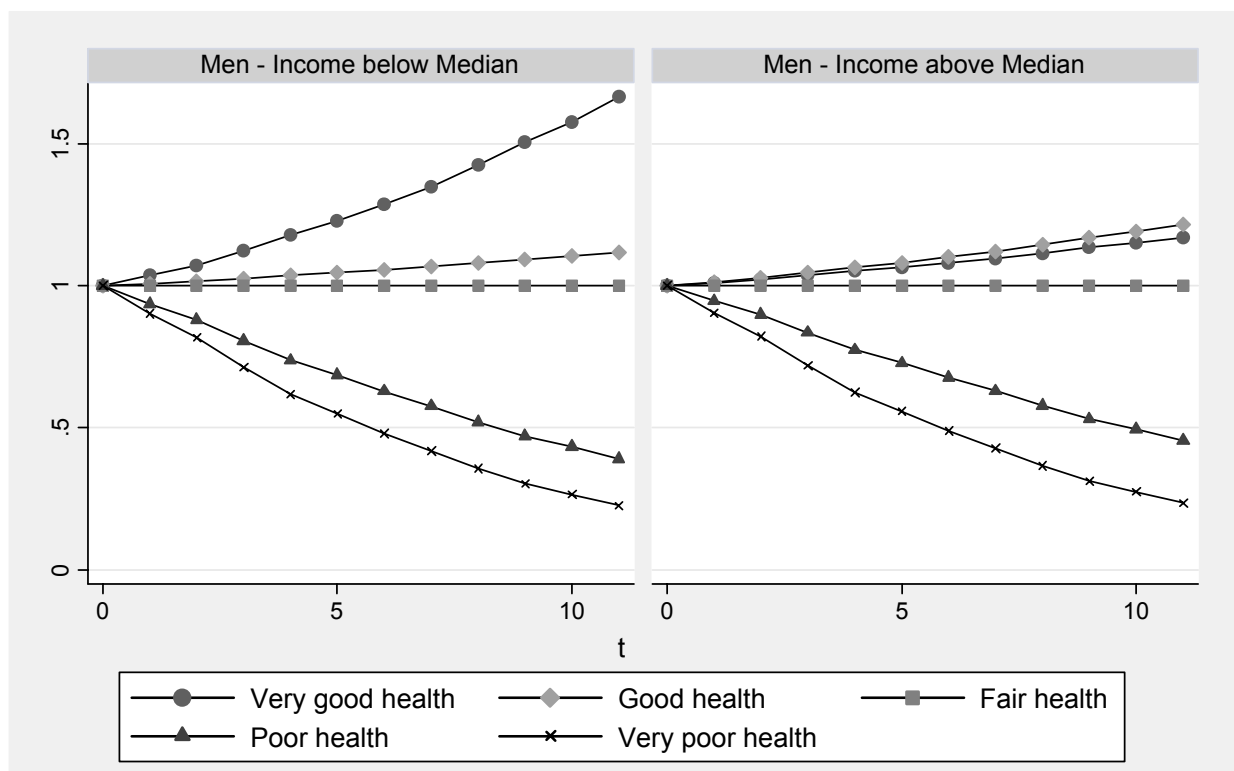

Figure 5a: Interaction effects of self-assessed health and income on predicted survival rates of men (Source: SOEP 1992-2003)

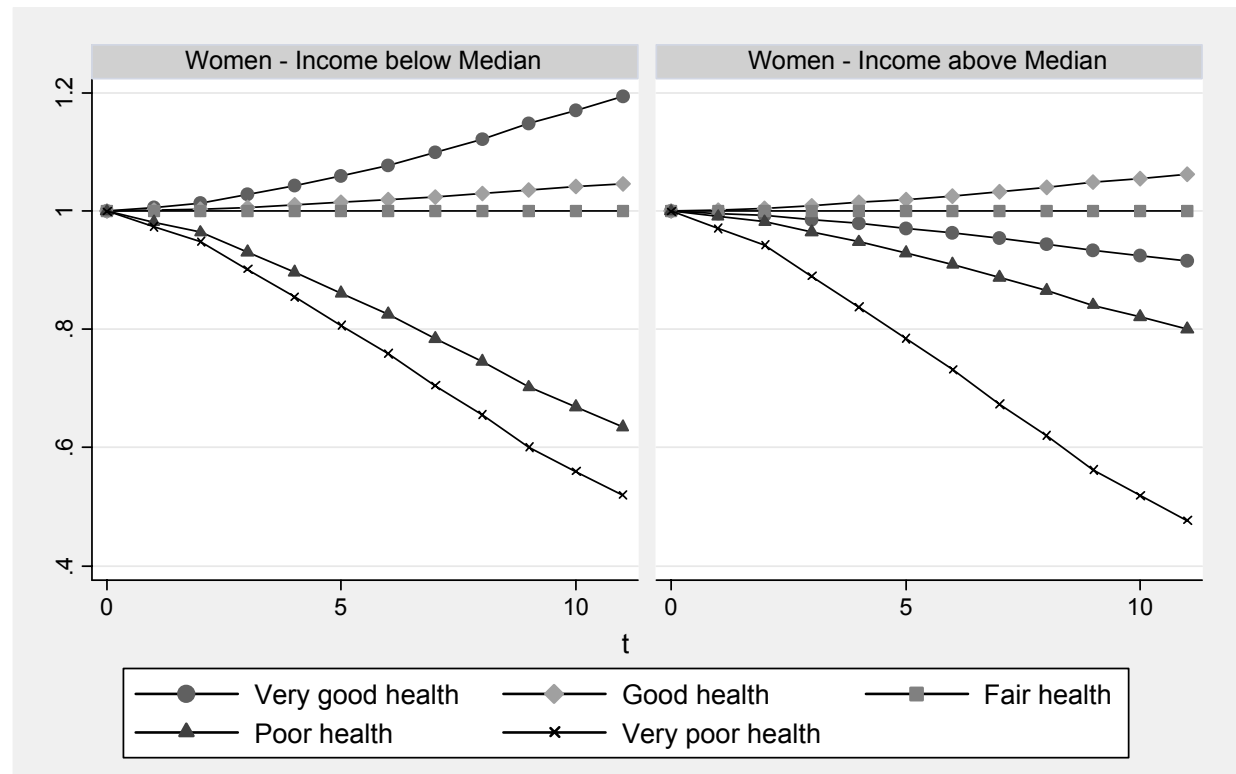

Figure 5b: Interaction effects of self-assessed health and income on predicted survival rates of women (Source: SOEP 1992-2003) 


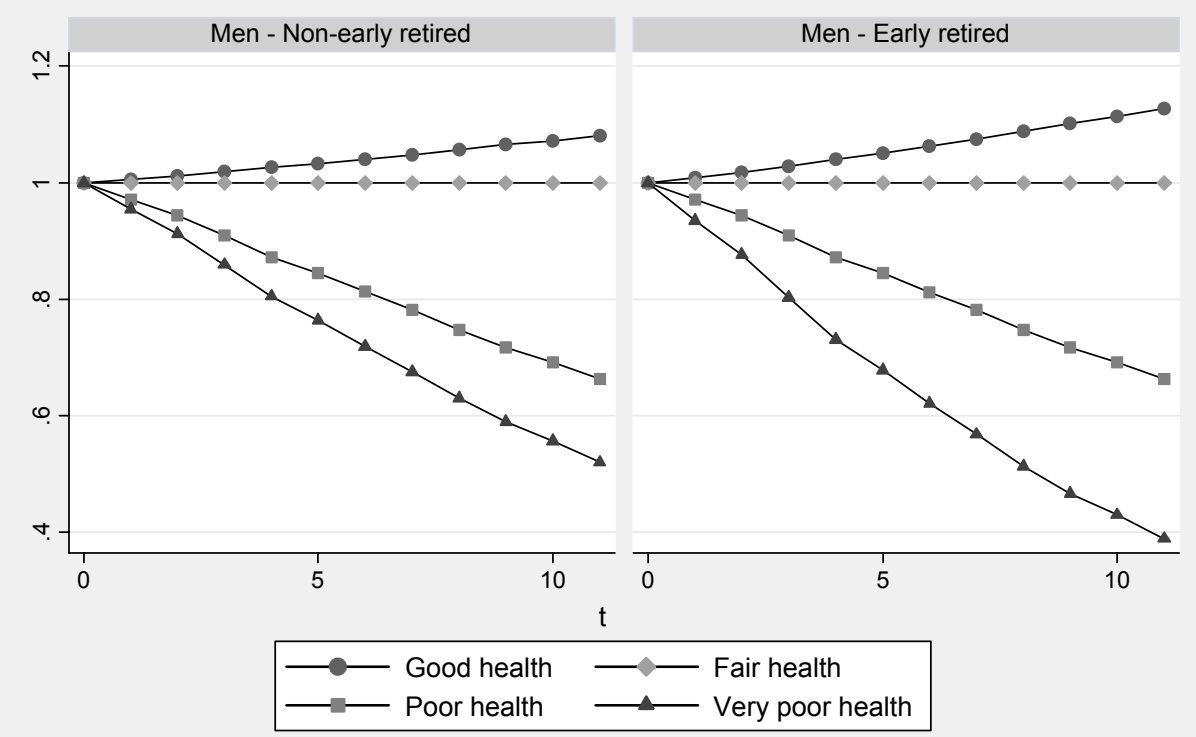

Figure 6a: Interaction effects of self-assessed health and early retirement on predicted survival rates of men (Source: SOEP 1992-2003)

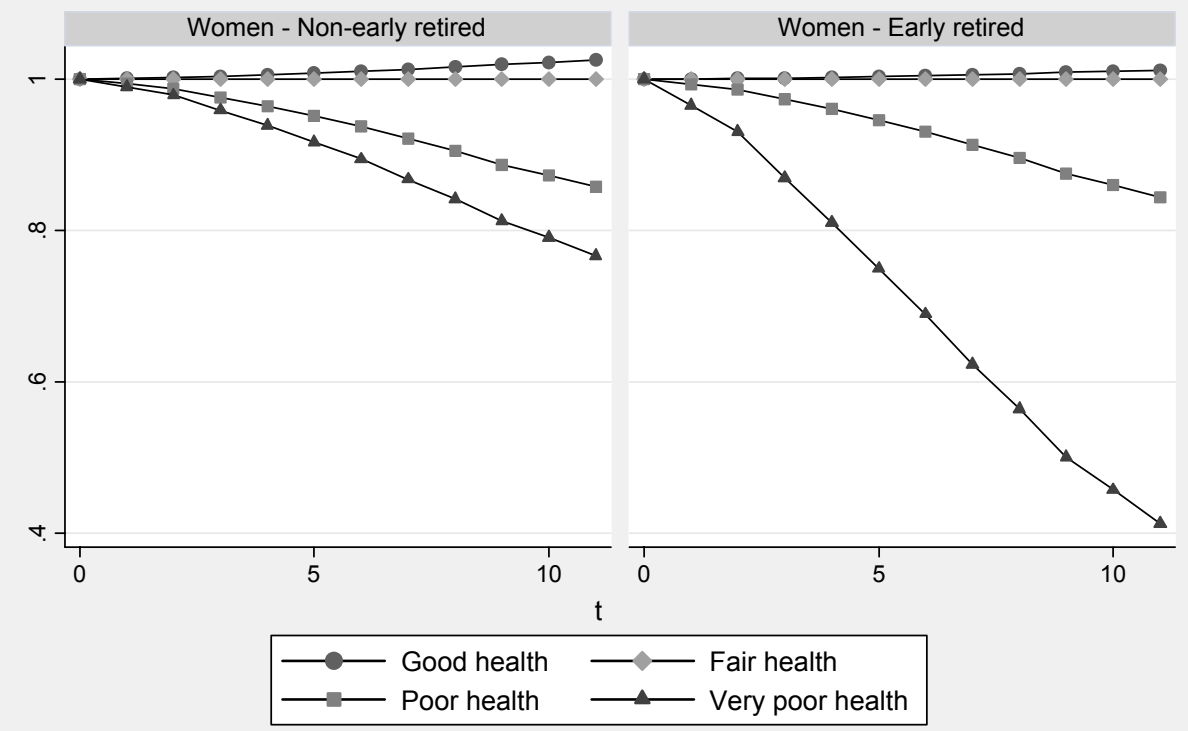

Figure 6b: Interaction effects of self-assessed health and income on predicted survival rates of women (Source: SOEP 1992-2003) 


\section{Discussion Paper Series}

Mannheim Research Institute for the Economics of Aging Universität Mannheim

To order copies, please direct your request to the author of the title in question.

\begin{tabular}{|c|c|c|c|}
\hline Nr. & Autoren & Titel & Jahr \\
\hline $44-04$ & $\begin{array}{l}\text { Alexander Ludwig } \\
\text { and Torsten Sløk }\end{array}$ & $\begin{array}{l}\text { The relationship between stock prices, house } \\
\text { prices and consumption in OECD countries }\end{array}$ & 04 \\
\hline $45-04$ & Matthias Weiss & $\begin{array}{l}\text { Skill-Biased Technological Change: Is there Hope } \\
\text { for the Unskilled? }\end{array}$ & 04 \\
\hline $46-04$ & $\begin{array}{l}\text { Hans-Martin von } \\
\text { Gaudecker }\end{array}$ & $\begin{array}{l}\text { Regionale Mortalitätsunterschiede in Baden- } \\
\text { Württemberg }\end{array}$ & 04 \\
\hline $47-04$ & Karsten Hank & $\begin{array}{l}\text { Effects of Early Life Family on Women's Late Life } \\
\text { Labour Market Behaviour: An Analysis of the } \\
\text { Relationship between Childbearing and } \\
\text { Retirement in Western Germany }\end{array}$ & 04 \\
\hline $48-04$ & $\begin{array}{l}\text { Christina Benita } \\
\text { Wilke }\end{array}$ & $\begin{array}{l}\text { Ein Simulationsmodell des Rentenversiche- } \\
\text { rungssystems: Konzeption und ausgewählte } \\
\text { Anwendungen von MEA-PENSIM }\end{array}$ & 04 \\
\hline $49-04$ & $\begin{array}{l}\text { Axel Börsch-Supan, } \\
\text { Alexander Ludwig } \\
\text { und Anette Reil-Held }\end{array}$ & $\begin{array}{l}\text { Hochrechnungsmethoden und Szenarien für } \\
\text { gesetzliche und private Renteninformationen }\end{array}$ & 04 \\
\hline $50-04$ & Axel Börsch-Supan & $\begin{array}{l}\text { From Public Pensions to Private Savings: The } \\
\text { Current Pension Reform Process in Europe }\end{array}$ & 04 \\
\hline $51-04$ & Axel Börsch-Supan & $\begin{array}{l}\text { Gesamtwirtschaftliche Folgen des } \\
\text { demographischen Wandels }\end{array}$ & 04 \\
\hline $52-04$ & Axel Börsch-Supan & $\begin{array}{l}\text { Mind the Gap: The Effectiveness of Incentives to } \\
\text { Boost Retirement Saving in Europe }\end{array}$ & 04 \\
\hline $53-04$ & Joachim Winter & & 04 \\
\hline $54-04$ & Axel Börsch-Supan & $\begin{array}{l}\text { Aus der Not eine Tugend - Zukunftsperspektiven } \\
\text { einer alternden Gesellschaft }\end{array}$ & 04 \\
\hline $55-04$ & Axel Börsch-Supan & Global Aging - Issues, Answers, More Questions & 04 \\
\hline $56-04$ & Axel Börsch-Supan & $\begin{array}{l}\text { Was bedeutet der demographische Wandel für die } \\
\text { Wirtschaft Baden-Württembergs? }\end{array}$ & 04 \\
\hline $57-04$ & Hendrik Jürges & $\begin{array}{l}\text { Self-assessed health, reference levels, and } \\
\text { mortality }\end{array}$ & 04 \\
\hline
\end{tabular}


